\title{
Assessment of selected heavy metal concentration in fresh and grilled beef - A case study in East Legon, Ghana
}

\author{
Frederick Adzitey ${ }^{1,2}$, David Mireku² and Nurul Huda3,4
}

1. Department of Veterinary Science, University for Development Studies, Box TL 1882, Tamale, Ghana; 2. Department of Animal Science, University for Development Studies, Box TL 1882, Tamale, Ghana; 3. School of Food Industry, Faculty of Bioresources and Food Industry, Universiti Sultan Zainal Abidin, UNISZA 22200, Besut, Terengganu Darul Iman, Malaysia; 4. Institute for Community (Health) Development, Universiti Sultan Zainal Abidin, UNISZA 21300, Gong Badak Campus, Terengganu Darul Iman, Malaysia.

Corresponding author: Frederick Adzitey, e-mail: adzitey@yahoo.co.uk

Co-authors: DM: davidmireku22@gmail.com, NH: nhuda@unisza.edu.my

Received: 14-06-2018, Accepted: 25-07-2018, Published online: 31-08-2018

doi: 10.14202/IJOH.2018.40-44 How to cite this article: Adzitey F, Mireku D, Huda N. Assessment of selected heavy metal concentration in fresh and grilled beef - A case study in East Legon, Ghana. Int J One Health 2018;4:40-44.

\begin{abstract}
Aim: Contamination of meat by heavy metals is a concern due to their possible toxicity and effects on human health. The present study was undertaken to determine the presence and concentration of iron $(\mathrm{Fe})$, zinc $(\mathrm{Zn})$, copper $(\mathrm{Cu})$, calcium $(\mathrm{Ca})$, manganese $(\mathrm{Mg})$, lead $(\mathrm{Pb})$, and cadmium $(\mathrm{Cd})$ in the fresh and grilled beef sold by kebab sellers in East Legon.

Materials and Methods: A total of 16 fresh and 16 grilled beef samples were collected purposely from three popular kebab sellers (School Junction, Bawalashie, and Otano) in East Legon. Beef samples were dried and digested to obtain a filtrate. The filtrate was analyzed using atomic absorption spectroscopy to determine the presence and concentration of the heavy metals.

Results: The concentration of the heavy metals ranged from 0.80 to $16.43 \mathrm{mg} / \mathrm{kg}$ for Fe, 0.05 to $0.27 \mathrm{mg} / \mathrm{kg}$ for $\mathrm{Zn}, 0.09$ to $2.10 \mathrm{mg} / \mathrm{kg}$ for $\mathrm{Cu}, 51.74$ to $90.83 \mathrm{mg} / \mathrm{kg}$ for $\mathrm{Ca}$, and 0.26 to $0.52 \mathrm{mg} / \mathrm{kg}$ for $\mathrm{Mg}$. There was statistical difference ( $\mathrm{p}=0.001)$ in the concentration of $\mathrm{Fe}, \mathrm{Zn}, \mathrm{Cu}$, and $\mathrm{Ca}$ in the fresh and grilled beef samples. The concentration of $\mathrm{Mg}$ in the fresh and grilled beef samples did not differ statistically $(\mathrm{p}=0.370)$. $\mathrm{Pb}$ and $\mathrm{Cd}$ were not detected in the beef samples examined. The concentration of $\mathrm{Fe}$ was highest in the grilled beef samples obtained from Bawalashie and lowest in the fresh beef samples obtained from Otano. The concentration of Ca was highest in the grilled beef samples obtained from School Junction (SG) and lowest in Bawalashie. The concentration of $\mathrm{Mg}$ was highest in the fresh beef samples obtained from SG and lowest in the grilled beef samples obtained from Bawalashie.
\end{abstract}

Conclusion: The study revealed the presence and absence of some heavy metals. Heavy metals present were available in varying concentrations. All trace elements were below the maximum limit, hence making it less harmful for consumption.

Keywords: concentration, fresh beef, grilled beef, heavy metal.

\section{Introduction}

Kebab refers to a dish of pieces of meat, fish, or vegetables roasted or grilled on a skewer or split [1]. Kebab vending in cities and certain corners of Ghana has sprung up rapidly due to the benefits sellers and consumers obtained from the business. Shekhar [2] reported that street vending is an activity that has employed many, while providing nutritious, inexpensive, and ready-to-eat food to millions of workers. Foods sold by street vendors stand a high chance of being contaminated due to their extensive exposure to contaminants such as microorganisms and heavy metals found or floating in the air. These contaminants can end up in food, meat, or meat products

Copyright: Adzitey, et al. This article is an open access article distributed under the terms of the Creative Commons Attribution 4.0 International License (http://creativecommons.org/licenses/ by/4.0/), which permits unrestricted use, distribution, and reproduction in any medium, provided you give appropriate credit to the original author(s) and the source, provide a link to the Creative Commons license, and indicate if changes were made. The Creative Commons Public Domain Dedication waiver (http:// creativecommons.org/ publicdomain/zero/1.0/) applies to the data made available in this article, unless otherwise stated. unintentionally [3]. They may originate from the environment or during processing and have reached the environment as a consequence of human activity [3].

Heavy metals have been defined based on their densities, atomic weights, atomic number, chemical properties, toxicity, and nomenclature. For instance, Duffus [4] indicated that density criteria range from above $3.5 \mathrm{~g} / \mathrm{cm}^{3}$ to $7 \mathrm{~g} / \mathrm{cm}^{3}$ and that of atomic weight definition range from higher than sodium (with an atomic weight of 22.98). According to the Environmental Protection Agency (EPA), heavy metals are metallic elements with a high atomic weight which can damage living things at low concentrations and tend to accumulate in the food chain [5]. These metals have maximum inclusion levels, and the amount of residue found in food must be safe for consumption and must be kept as low as possible.

The presence of heavy metals in meat degrades its quality, which eventually affects human health. The consumption of the contaminated food with heavy metals such as lead $(\mathrm{Pb})$ and cadmium $(\mathrm{Cd})$ at maximum levels can affect different organs and systems 
in humans including the peripheral and central nervous system, gastrointestinal tract, muscles, kidneys, liver, and hepatic system [6]. It can also lead to the development of neurological symptoms such as headaches, lethargy, fatigue, peripheral neuropathy, severe convulsions, and encephalopathy [6]. Ignorance on the part of consumers towards heavy metals and their effects increases the risk of humans to heavy metals poisoning. There is, therefore, the need to determine the presence of these heavy metals in meats and other food products sold in Ghana and the world at large. This will serve as a guide to help in various remediation activities and also to create awareness concerning its exposure and effects in relation to humans.

The objective of this study was to determine the presence and concentration of selected heavy metals (iron $[\mathrm{Fe}]$, zinc $[\mathrm{Zn}]$, copper $[\mathrm{Cu}]$, calcium $[\mathrm{Ca}]$, manganese $[\mathrm{Mg}], \mathrm{Pb}$, and $\mathrm{Cd}$ ) in fresh and grilled beef sold by kebab sellers in East Legon, Accra.

\section{Materials and Methods}

\section{Ethical approval}

All samples were collected as per the standard sample collection procedure without harming humans or animals.

\section{Study area}

This study was conducted in East Legon, a suburb of Accra (capital of Greater Accra Region). It is $13 \mathrm{~km}$ northeast of the city center and occupies a total area of $4.95 \mathrm{~km}^{2}$ [7]. East Legon is noted for its sophisticated modern low-rise apartment blocks and detached houses. The area is sparsely populated and occupied mainly by high-income groups and foreigners. East Legon is found on the eastern side of Legon, and it is a 16-min drive from airport city. Figure-1 shows a map of East Legon.

\section{Sample collection and preparation for analysis}

The grilled and fresh beef samples were obtained from three most popular kebab sellers (School Junction, Bawalashie, and Otano) in East Legon. 36 samples of beef were obtained, i.e., six raw beef and six grilled beef samples from each kebab seller. The various samples were packed using sterilized plastic bags and placed in an ice chest containing ice. The samples were transported immediately to the Food Research Institute (Council for Scientific and Industrial Research [CSIR]), Accra, for heavy metal determination.

\section{Heavy metal determination}

The heavy metal determination was carried out at Food Research Institute a branch of the CSIR in Accra. The determination of heavy metals was done according to Pequerul et al. [8]. Briefly, the samples were labeled appropriately and blended into smaller sizes. Samples were then oven dried at $600^{\circ} \mathrm{C}$ for $15 \mathrm{~min}$ to get rid of moisture and allowed to cool overnight. The ash residue was then subjected to wet digestion after cooling. The various ash residues were placed into labeled crucibles, and $2.5 \mathrm{ml}$ of sulfuric acid was added into it. The crucibles were heated for $30 \mathrm{~min}$ and allowed to cool. After digestion, $10 \mathrm{ml}$ of $\mathrm{HNO}_{3}$ was added in dropwise until a clear solution was obtained. The content was then heated for $1 \mathrm{~h}$ and allowed to cool. The content in the crucibles was then filtered into a $50 \mathrm{ml}$ volumetric flask and made up to the mark with distilled water. The content was heated for $15 \mathrm{~min}$ and allowed to cool. The resultant filtrate was then fed into a machine known as the Atomic Absorption Spectrometer to determine the presence and the concentration of the selected heavy metals.

\section{Statistical analysis}

Data obtained were subjected to the analysis of variance using ANOVA in GenStat Release $12^{\text {th }}$ Edition. Means were separated at 5\% significance level.

\section{Results}

The study revealed the presence and absence of heavy metals in both the fresh and grilled beef samples. The concentration of heavy metals

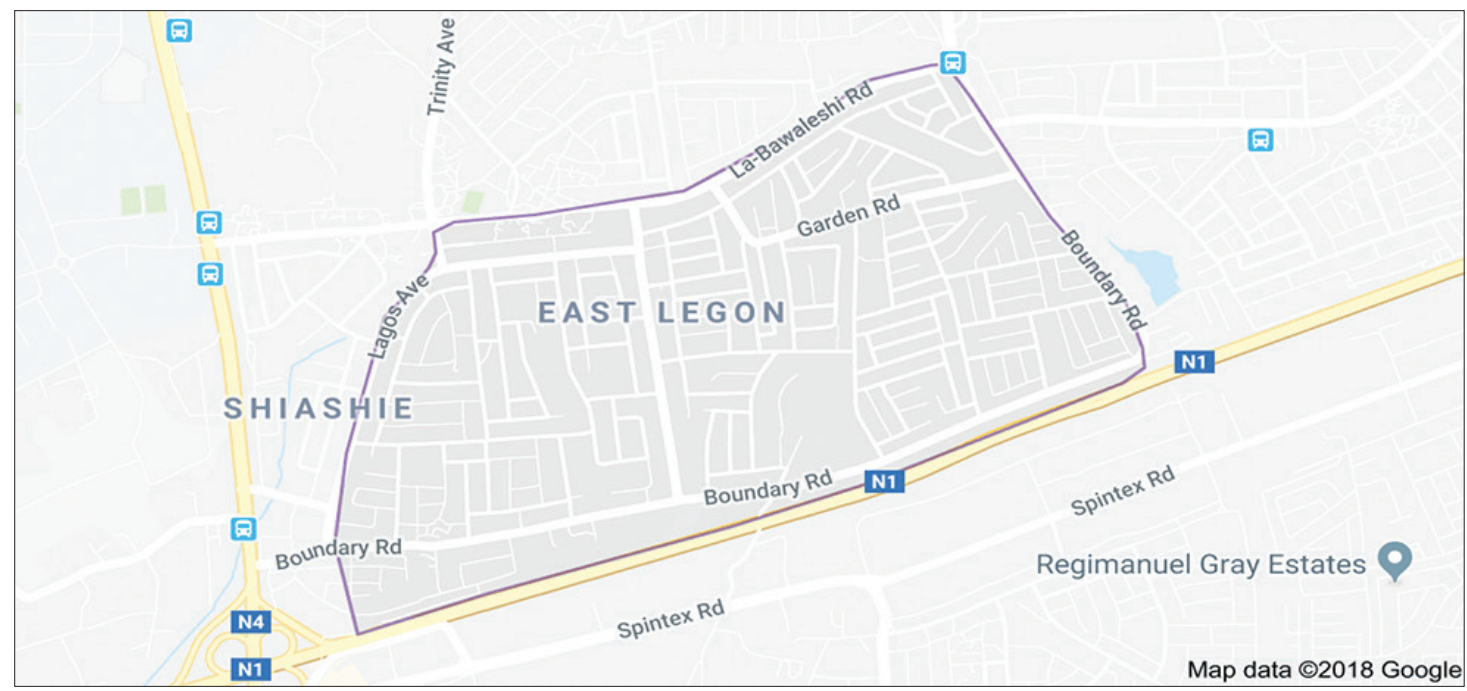

Figure-1: Map of East Legon. Source: Google Map. 
present varied among beef samples examined. Heavy metals quantified in beef samples were statistically significant $(\mathrm{p}<0.05 \%)$ among samples with the exception of $\mathrm{Mg}$, and $\mathrm{Pb}$ and $\mathrm{Cd}$ which were not detected in any of the samples examined (Table-1). The concentration of $\mathrm{Fe}$ in beef samples collected was generally high compared to the other metals studied except Ca. Fresh beef samples obtained from Bawalashie had the highest concentration of $\mathrm{Fe}$, while fresh beef samples obtained from Otano had the lowest concentration of Fe. The concentration of $\mathrm{Zn}$ was highest in fresh beef samples obtained from Bawalashie and the least concentration was observed in the grilled beef samples obtained from School Junction. The highest concentration of $\mathrm{Cu}$ was observed in the fresh beef samples obtained from School Junction, while the lowest concentration of $\mathrm{Cu}$ was observed in grilled beef samples collected from School junction. Ca had the highest concentration values compared to the other metals. The highest concentration of $\mathrm{Ca}$ was observed in grilled beef samples obtained from School junction. and the least concentration was observed in fresh beef samples obtained from School junction. The concentration of $\mathrm{Mg}$ was highest in fresh beef samples obtained from School junction and least in the grilled beef samples obtained from Otano.

\section{Discussion}

$\mathrm{Cd}$ was not detected in the fresh and grilled beef samples examined. The inability to detect $\mathrm{Cd}$ in the sample might be as a result of very low levels or absence of $\mathrm{Cd}$ in the meat samples collected. Adzitey et al. [9] reported on the absence of $\mathrm{Cd}$ in fresh and grilled beef samples obtained in Tamale, Ghana. Contrarily, Adetunjia et al. [10] found $\mathrm{Cd}$ in cattle liver, kidney, and muscles collected from a slaughter slab in Nigeria. Cd was also identified in exposed corned beef and chicken luncheon sold in Sulaymaniyah market [11]. The absence of $\mathrm{Cd}$ in the fresh beef samples showed that the animals were not exposed to $\mathrm{Cd}$ contaminants and $\mathrm{Cd}$-containing feed.
$\mathrm{Pb}$ was also not detected in the fresh and grilled beef samples examined. The inability to detect $\mathrm{Pb}$ in the beef samples might also be as a result of very low levels or absence of $\mathrm{Pb}$ in meat samples collected. Landis and $\mathrm{Yu}$ [12] reported high levels of $\mathrm{Pb}$ which was due to the spices used during the processing of meatballs, corned beef, burger's beef, and sausages. Adetunjia et al. [10] also found $\mathrm{Pb}$ in cattle liver, kidney, and muscles collected from a slaughter slab in Nigeria. Adzitey et al. [9] reported the presence of $\mathrm{Pb}$ in both fresh and grilled beef sold in Tamale. The absence of $\mathrm{Pb}$ in the fresh meat indicates that animals were not exposed to water contaminated by $\mathrm{Pb}$ and $\mathrm{Pb}$-containing feed.

The grilled beef samples collected from Bawalashie had higher concentrations of $\mathrm{Fe}$, and the minimum concentration was observed in the fresh meat samples collected from Otano. The samples collected from the various kebab vendors showed higher levels of $\mathrm{Fe}$ in the grilled samples than the fresh meat samples collected. Increase in the concentration of Fe in the grilled meat samples obtained maybe as a result of spices used in seasoning the meat. Nkansah and Cosmos [13] in their study reported on the presence of $\mathrm{Fe}$ in local spices such as garlic, ginger, and pepper which are commonly used in kebab preparation. The iron concentration was $1.382 \pm 0.130,2.881 \pm 0.131$ and $4.942 \pm 0.200$, for garlic, ginger and pepper, respectively [13]. The presence of $\mathrm{Fe}$ in the fresh samples also showed that the animals were exposed to feed containing $\mathrm{Fe}$. The concentration of $\mathrm{Fe}$ detected in this study as shown in Table-1 ranged from 1.30 to 16.43 $\mathrm{mg} / \mathrm{kg}$. With the exception of the Fe concentration of fresh beef samples obtained from Otano and School Junction, the rest of the beef samples were within the recommended daily allowance of $15 \mathrm{mg}$ per day as reported by Lenntech [14]. The concentration of Fe in beef samples examined in this study were lower than those reported by Iwegbue et al. [15], for chicken meat, gizzard, and turkey meat consumed in Nigeria. Fe levels for chicken meat, gizzard, and turkey ranged from 22.07 to $97.72 \mathrm{mg} / \mathrm{kg}, 19.28$ to $45.72 \mathrm{mg} / \mathrm{kg}$, and 14.14 to 35.03 , respectively [15].

Table-1: Concentration of selected heavy metals in the fresh and grilled beef samples.

\begin{tabular}{|c|c|c|c|c|c|c|c|c|}
\hline \multicolumn{9}{|l|}{ Sample } \\
\hline Heavy metals & BF & BG & OF & OG & $\mathbf{S F}$ & SG & LSD & $\mathbf{p}$ \\
\hline $\mathrm{Fe}(\mathrm{mg} / \mathrm{kg})$ & $9.50^{c}$ & $16.43^{\mathrm{a}}$ & $0.80^{d}$ & $9.35^{c}$ & $1.30^{\mathrm{d}}$ & $11.33^{\mathrm{b}}$ & 0.504 & 0.001 \\
\hline $\mathrm{Zn}(\mathrm{mg} / \mathrm{kg})$ & $0.27^{a}$ & $0.11^{\mathrm{cd}}$ & $0.18^{\mathrm{bc}}$ & $0.07^{d}$ & $0.24^{\mathrm{ab}}$ & $0.05^{d}$ & 0.074 & 0.001 \\
\hline $\mathrm{Cu}(\mathrm{mg} / \mathrm{kg})$ & $1.90^{\mathrm{a}}$ & $0.09^{c}$ & $0.98^{b}$ & $0.60^{\mathrm{b}}$ & $2.10^{\mathrm{a}}$ & $0.12^{c}$ & 0.44 & 0.001 \\
\hline $\mathrm{Ca}(\mathrm{mg} / \mathrm{kg})$ & $51.74^{\mathrm{e}}$ & $59.71^{d}$ & $80.93^{b}$ & $80.93^{b}$ & $77.32^{c}$ & $90.83^{a}$ & 2.124 & 0.001 \\
\hline $\mathrm{Mg}(\mathrm{mg} / \mathrm{kg})$ & 0.45 & 0.3 & 0.4 & 0.26 & 0.52 & 0.39 & 0.269 & 0.37 \\
\hline $\mathrm{Pb}(\mathrm{mg} / \mathrm{kg})$ & 0 & 0 & 0 & 0 & 0 & 0 & ND & ND \\
\hline $\mathrm{Cd}(\mathrm{mg} / \mathrm{kg})$ & 0 & 0 & 0 & 0 & 0 & 0 & ND & ND \\
\hline
\end{tabular}

Means within the same row with different superscripts are significantly different $(p<0.05)$. BF=Fresh beef samples obtained from Bawalashie (Jerry's Pub), BG=Grilled beef samples obtained from Bawalashie (Jerry's Pub), OF=Fresh beef samples obtained from Otano (Atinga Kebab), OG=Grilled beef samples obtained from Otano (Atinga Kebab), $\mathrm{SF}=$ Fresh beef samples obtained from School Junction (Morocco Spot), SG=Grilled beef samples obtained from School Junction (Morocco Spot), ND=Not determined, $\mathrm{Fe}=$ Iron, $\mathrm{Zn}=\mathrm{Zinc}, \mathrm{Cu}=$ Copper, $\mathrm{Ca}=$ Calcium, Mg=Manganese, $\mathrm{Pb}=\mathrm{Lead}$, $\mathrm{Cd}=$ Cadmium 
$\mathrm{Zn}$ concentration was lowest in the grilled beef samples collected from School Junction and highest in the fresh beef samples collected from Bawalashie. Zn is an essential trace element for the livelihood of animals and humans. $\mathrm{Zn}$ concentration was high in fresh samples but reduced on grilling. Adzitey et al. [9] reported on high $\mathrm{Zn}$ concentration in fresh beef samples relative to their corresponding grilled samples. Too little $\mathrm{Zn}$ can cause problems and too much $\mathrm{Zn}$ is harmful to human health [16]. The presence of $\mathrm{Zn}$ in the fresh meat samples indicated that animals were exposed to $\mathrm{Zn}$ before slaughtering, either through inhalation or ingestion. According to the Agency for Toxic Substances and Disease Registry [16], $\mathrm{Zn}$ is said to be the most common element found in the earth's crust and it is found in the air, soil and water, and presents in all foods. Zn concentration in this study ranged from 0.05 to $0.27 \mathrm{mg} / \mathrm{kg}$ which is very low as compared to the recommended daily allowance of $60 \mathrm{mg} /$ day as indicated by Koréneková et al. [17].

$\mathrm{Ca}$ is an essential mineral for both animals and humans. Too little $\mathrm{Ca}$ may result in $\mathrm{Ca}$ deficiency which causes many bone diseases. The highest concentration of $\mathrm{Ca}$ in samples collected was observed in the grilled beef samples obtained from School Junction, whereas the lowest concentration was seen in the fresh beef samples obtained from Bawalashie. Results in Table- 1 showed an increase in $\mathrm{Ca}$ concentration on grilling. The presence of $\mathrm{Ca}$ in the fresh meat samples indicate that animals were exposed to $\mathrm{Ca}$ before they were slaughtered. Ca concentration ranged from 51.75 to $90.83 \mathrm{mg} / \mathrm{kg}$. This range is below the recommended dietary allowance reported by The Institute of Medicine [18]. According to The Institute of Medicine [18], the recommended dietary allowance for $\mathrm{Ca}$ for ages $0-12$ months range from 200 to $260 \mathrm{mg} / \mathrm{kg}$; for ages 1-8 years, it ranges from $700-1300 \mathrm{mg} / \mathrm{kg}$; for ages 9-18 years, the recommended dietary allowance is $1300 \mathrm{mg} / \mathrm{kg}$; and from ages 19 to 70 years, the recommended dietary allowance ranges from 1000 to $1200 \mathrm{mg} / \mathrm{kg}$.

The fresh beef samples contained the highest concentrations of $\mathrm{Cu}$ compared to grilled samples. Adzitey et al. [9] reported a decrease in $\mathrm{Cu}$ levels on grilling in guinea fowl samples obtained from Aboabo. Adzitey et al. [9] also reported on a decrease in $\mathrm{Cu}$ levels in samples obtained from Tishegu and an increase in $\mathrm{Cu}$ concentration upon grilling in samples obtained from Victory Cinema. This could be attributed to the fact that animals were exposed to $\mathrm{Cu}$-containing feed and drinking water contaminated by $\mathrm{Cu}$ before slaughtering. The levels of $\mathrm{Cu}$ observed in both the fresh and grilled beef samples collected from the three kebab vendors fell within the recommended daily allowance of $2 \mathrm{mg}$ as reported by Lenntech [14] and as little as $10 \mathrm{mg}$ of $\mathrm{Cu}$ can have a toxic effect [14]. According to the World Health Organization [19], the recommended dietary allowance for adults is $0.9 \mathrm{mg} /$ day. From this study, $\mathrm{Cu}$ found in beef samples collected from Bawalashie, Otano, and School Junction were below the maximum permissible limits or recommended daily allowance. The concentration levels of $\mathrm{Cu}$ in this study was found to be higher than the $\mathrm{Cu}$ levels found in guinea fowl meat sold in Tamale as reported by Adzitey et al. [9]. Adzitey et al. [9] reported $\mathrm{Cu}$ levels of $0.0498-0.0882 \mathrm{mg} / \mathrm{kg}$ which is lower than the levels found in this study.

The highest concentration of $\mathrm{Mg}$ was found in the fresh beef samples collected from School Junction and the lowest was found in the grilled beef samples collected from Otano. The presence of $\mathrm{Mg}$ in beef meat samples might be as a result of salt and spices used in seasoning the meat before grilling. The recommended daily intake of $\mathrm{Mg}$ is $5 \mathrm{mg}$ [14]. The $\mathrm{Mg}$ levels in this study were found to be lower than the tolerance intake for humans.

\section{Conclusion}

Beef samples contained the heavy metals analyzed for including $\mathrm{Fe}, \mathrm{Zn}, \mathrm{Cu}, \mathrm{Ca}$, and $\mathrm{Mg}$ except $\mathrm{Cd}$ and $\mathrm{Pb}$ which was absent. This suggested that animals were not exposed to harmful or toxic trace elements during feeding or the procedure involved in processing beef was not exposed to $\mathrm{Pb}$ or $\mathrm{Cd}$ contamination. The concentration of heavy metals detected varied. Concentrations of all the trace elements detected were below or fell within consumable limits. Hence, the grilled beef products sold in East Legon is wholesome for consumption in terms of $\mathrm{Cu}, \mathrm{Mg}, \mathrm{Ca}, \mathrm{Zn}$, and Fe. Nevertheless, to meet the daily requirement for $\mathrm{Fe}, \mathrm{Zn}$, and $\mathrm{Ca}$ additions must be acquired from other food sources.

\section{Authors' Contributions}

FA: Provided part of laboratory supplies, developed the concept/proposal and wrote the manuscript. DM: Provided part of the laboratory supplies and participated in the laboratory work and manuscript writing. NH: Participated in concept development, manuscript editing, and handling fees. All authors read and approved the final manuscript.

\section{Acknowledgments}

We acknowledge the support given by the University for Development Studies, Food Research Institute, and Universiti Sultan Zainal Abidin to run this experiment. This work was funded by the authors.

\section{Competing Interests}

The authors declare that they have no competing interests.

\section{References}

1. Oxford Dictionary: Heavy Metals, 2016. Available from: http://www.dictionary.com. [Last accessed on 06-04-2016].

2. Shekhar H. Street Foods and its Implication for Food Safety in the Context of Bangladesh, 2010. Available from: http:// www.voctabangladesh.org/articles/street-foods-and-itsimplication-or-food-safety-in-the-context-of-Bangladesh. [Last accessed on 03-12-2016].

3. Bundesinstitut Für Risikobewertung: Health Assessment 
of Residues in Foods, 2013. Available from: http://www. bfr.bund.de/.../health_assessment_of_residues_in_foods76731.hmtl. [Last accessed on 03-12-2016].

4. Duffus JH. "Heavy metals"-a meaningless term? Pure Appl Chem 2002;74:793-807.

5. Eco-USA: Heavy Metals, 2016. Available from: http://www. eco-usa.net/toxics/heavy_metals.shtml. [Last accessed on 2016 Dec 02]; [Last accessed on 2016 Dec 03].

6. Ciobanu C, Slencu BG, Cuciureanu R. Estimation of dietary intake of cadmium and lead through food consumption. Rev Med Chir Soc Med Nat Iasi 2012;116:617-23.

7. Anonymous. East Legon, 2017. Available from: https:// www.en.wikipedia.org/wiki/East_Legon. [Last accessed on 03-12-2016].

8. Pequerul A, Pérez C, Madero P, Val J, Monge E. A Rapid Wet Digestion Method for Plant Analysis, 1993. Available from: http://www.link.springer.com/chapter/10.1007\%2F978-94017-2496-8_1. [Last accessed on 03-12-2016].

9. Adzitey F, Kumah A, Mensah SB. Assessment of the presence of selected heavy metals and their concentration levels in fresh and grilled beef/guinea fowl meat in the Tamale Metropolis, Ghana. Res J Environ Sci 2015;9:152-8.

10. Adetunjia VO, Famakina IO, Chenb J. Lead and cadmium levels in cattle muscle and edible tissues collected from a slaughter slab in Nigeria. Food Add Cont Part B 2014;7:79-83.

11. Hamasalim HJ, Mohammed HN. Determination of heavy metals in exposed corned beef and chicken luncheon that sold in Sulaymaniah Markets. Afr J Food Sci 2013;7:178-82.

12. Landis $\mathrm{WG}, \mathrm{Yu} \mathrm{MH}$. Introduction to Environmental
Toxicology; Impacts of Chemicals Upon Ecological System. Boca Raton, FL: Lewis Publishers, CRC Press, LLC; 2004. p. 221-3.

13. Nkansah MA, Cosmos OA. Heavy metal content of some local spices available in markets in the Kumasi Metropolis of Ghana. Am J Sci Ind Res 2010;1:158-63.

14. Lenntech BV. Recommended Daily Intake of Vitamins and Minerals, 2016. Available from: http://www.lenntech. com/recommended-daily-intake.htm. Last accessed on 03-12-2016].

15. Iwegbue CM, Nwajei GE, Iyoha EH. Heavy metal residue of chicken meat and gizzard and turkey meat consumed in southern Nigeria. Bul J Vet Med 2008;11:275-80.

16. Agency for Toxic Substances and Disease Registry (ATSDR) ATSDR. Toxicological Profile for Manganese. Atlanta, GA: United States Department of Health and Human Services, Public Health Service, Agency for Toxic Substances and Disease Registry; 2000. Available from: http://www.atsdr. cdc.gov/toxprofiles/tp.asp?id $=102 \&$ tid $=23$. [Last accessed on 03-12-2016].

17. Koréneková B, Skalická M, Naï P. Concentration of some heavy metals in cattle reared in the vicinity of a metallurgic industry. Vet Arh 2000;72:259-67.

18. The Institute of Medicine. Committee to Review Dietary Reference Intake for Vitamin D and Calcium, Food and Nutrition Board. Institute of Medicine. Washington DC: National Academy Press; 2011.

19. WorldHealth Organization. TraceElements in Human Nutrition and Health. Geneva: World Health Organization; 1996. 